This allows the varices to prolapse into the lumen of the instrument. It is then a simple matter to advance the needle directly into the varix.

The injection is made as near to the cardia as possible (see fig. (b)). After injecting $5 \mathrm{ml}$ of ethanolamine oleate the needle is withdrawn, and the oesophagoscope advanced to compress the site of the injection for one to two minutes (see fig. (c)). The oesophagoscope is then withdrawn to allow the widened proximal end which carries the lighting to emerge from the mouth so that the instrument can be rotated. It is then advanced again. Five or six sites equally spaced around the circumference of the lumen are usually injected at the first sitting; up to $30 \mathrm{ml}$ of sclerosant may be used. A SengstakenBlakemore tube may be passed if there is any significant bleeding; it is usually removed after six to 12 hours.

\footnotetext{
${ }^{1}$ Rothwell-Jackson, R. L., and Hunt, A. H., British fournal of Surgery, 1971, 58, 205.

2 George, P., et al., British fournal of Surgery, 1973, 60, 635.

3 Pugh, R. N. H., et al., British Fournal of Surgery, 1973, 60, 646.

4 Orloff, M. J, et al., Archives of Surgery, 1974, 108, 293.

5 Johnston, G. W., and Rodgers, H. W., British fournal of Surgery, 1973, 60,797 .
}

King's College Hospital, London S.E.5

M. E. BAILEY, F.R.C.S., Senior Surgical Registrar J. L. DAWSON, M.S., F.R.C.S., Consultant Surgeon

\section{Bone Marrow Suppression by Antilymphocytic Globulin}

The problem of suppressing bone marrow function by preparations of antilymphocytic globulin (A.L.G.) was reported at a recent conference on A.L.G. at the Royal College of Physicians. We report some preliminary studies which show that A.L.G. inhibits human bone marrow colony forming cells.

\section{Case Histories}

Burroughs Wellcome A.L.G. was studied as our group has used this preparation in marrow transplantation in two patients where acute graft-versushost disease followed marrow transplantation from a family donor judged compatible by H-LA typing and the mixed lymphocyte reaction. The first patient, a 6-month-old boy with severe combined immune deficiency disease, was given a single dose of A.L.G., $8 \mathrm{mg} / \mathrm{kg}$. This improved the graft-versus-host disease without impairing marrow function. The second patient, a 27 -year-old man with severe aplastic anaemia, received A.L.G., $10 \mathrm{mg} / \mathrm{kg}$, which abolished the graft-versus-host disease. No engraftment occurred and the patient died three days after a second graft was given.

To study bone marrow colony growth bone marrow in heparin was taken from haematologically normal patients. The buffy coat obtained by sedifrom haematologically normal patients. The bufry coat obtained by sedimentation was washed three times in culture medium and the cell count adjusted to 106 cells/ml. Marrow was incubated for three hours in the presence of A.L.G. in concentrations varying from $0 \mu \mathrm{g} / \mathrm{ml}-100 \mu \mathrm{g} / \mathrm{ml}$ with or without the addition of autologous serum as a source of complement. The marrow was then plated in soft agar on previously prepared periphera blood leucocyte feeder layers as a source of colony stimulating factor, using the method described by Pike and Robinson. ${ }^{1}$ After 10-14 days colony counts were performed on triplicate cultures and the results of two such experiments are shown in the table.

Bone Marrow Colony Growth after Incubation with A.L.G. or Horse Globulin

\begin{tabular}{|c|c|c|c|c|c|c|c|}
\hline \multirow{3}{*}{ Marrow } & \multirow{3}{*}{$\begin{array}{l}\text { Autologous } \\
\text { Serum }\end{array}$} & \multicolumn{6}{|c|}{$\begin{array}{l}\text { Colonies } / 3 \times 10^{5} \text { Cells Plated } \\
\text { Mean of Three Culture Plates }\end{array}$} \\
\hline & & \multirow{2}{*}{$\begin{array}{l}\text { Control } \\
\text { No Feeder }\end{array}$} & \multirow{2}{*}{ Control } & \multicolumn{4}{|c|}{ A.L.G. $\mu \mathrm{g} / \mathrm{ml}$} \\
\hline & & & & $0 \cdot 1$ & 1.0 & 10 & 100 \\
\hline \multirow[t]{3}{*}{$\begin{array}{l}1 \\
2 \\
1 \\
2\end{array}$} & \multirow[t]{3}{*}{$\begin{array}{l}\text { None } \\
\text { None } \\
0.1 \mathrm{ml} \\
0.1 \mathrm{ml}\end{array}$} & \multirow[t]{3}{*}{$\begin{array}{c}0 \\
1.0 \\
0.6 \\
2.0\end{array}$} & \multirow[t]{3}{*}{$\begin{array}{r}75 \\
141 \\
76 \\
145\end{array}$} & $\begin{array}{l}\frac{67 \cdot 6}{52 \cdot 3} \\
78\end{array}$ & $\begin{array}{c}56 \cdot 3 \\
158 \\
33 \cdot 3 \\
71\end{array}$ & $\begin{array}{l}31 \cdot 6 \\
94 \cdot 6 \\
25 \cdot 3 \\
23\end{array}$ & $\begin{array}{r}16.0 \\
73.0 \\
5.3 \\
5.5\end{array}$ \\
\hline & & & & \multicolumn{4}{|c|}{ Horse Globulin $\mu \mathrm{g} / \mathrm{ml}$} \\
\hline & & & & 0.1 & 1.0 & 10 & 100 \\
\hline 2 & $0.1 \mathrm{ml}$ & $2 \cdot 0$ & 145 & $97 \cdot 6$ & 118 & 163 & 159 \\
\hline
\end{tabular}

\section{Discussion}

The results show that A.L.G. significantly inhibits marrow colony formation at doses as low as $0.1 \mu \mathrm{g} / \mathrm{ml}(P=<0.05)$ and that fresh serum significantly enhances this effect $(P=0.005)$ while horse globulin causes no inhibition. A.L.G. causes depression of rat stem cells ${ }^{2}$ but no direct measure of human stem cells is available. The action of A.L.G. on human colony forming cells may be relevant to its harmful effect after marrow transplantation. Our preliminary experience shows that the dose of A.L.G. used may be critical in allowing marrow to take. We hope to use this technique to test a variety of A.L.G.s for marrow toxicity, and to investigate the possibility of removing the anti-stem-cell activity while preserving its antilymphocyte action by absorption with myeloid cells in the way Marmont described. ${ }^{3}$

${ }^{1}$ Pike, B. L., and Robinson, W. A., fournal of Cellular Physiology, 1970, 76, 77.

${ }^{2}$ Field, E. O., and Gibbs, J. E., Nature, 1968, 217, 561.

${ }^{3}$ Marmont, A. M., in Proceedings of the Symposium on Anti-lymphocyte Globulin in Clinical Practice, ed. R. Rousell. In press.

\section{Department of Haematology, Westminster Hospital, Dean Ryle} Street, London SW1P 2AP

A. J. BARRETT, M.B., B.S., Lecturer in Haematology

J. G. HUMBLE, F.R.C.P., F.R.C.PATH., Professor in Haematology

J. R. HOBBS, F.R.C.P., F.R.C.PATH., Professor in Chemical Pathology

\section{Postpartum Rubella Vaccination and Anti-D Prophylaxis}

Rubella vaccination of recently delivered women for preventing rubella and congenital malformations in future pregnancies is now routine. Simultaneously some patients run a risk of $R h$ immunization. As anti-D immunoglobulin preparations from pooled human sera, which should be administered post partum, also contain rubella antibodies, Alderman and Charles ${ }^{1}$ have recommended the postponement of rubella vaccination in these cases. This practice has several disadvantages; particularly if conception occurs during the viraemia. We have used an anti-D immunoglobulin preparation with a 1:1024 rubella HI-titre and studied its influence on the development of immunity after rubella vaccination.

\section{Case Histories}

We screened 587 antenatal patients for the presence or absence of rubella antibodies by a haemagglutination-inhibition method. No rubella antibodies were detectable (seronegative-that is, titre $<8$ ) in $6 \%$ of these patients. Twenty one and 25 were investigated in detail three and six weeks after vaccination, respectively. Previous experience had shown that seropositive patients with titres as low as $1: 8$ did not show an appreciable antibody titre rise after rubella vaccination. Patients in group A received the rubella vaccine- $0.5 \mathrm{ml}$ of live, attenuated rubella virus vaccine duck embryo cell-5 apted HPV-77 strain, containing not less than 1000 TCID of rubell virus (Meruvax MSD) ( ( given $250 \mathrm{\mu g}$ anti-D immunoglobulin in $2 \mathrm{ml}$ of a $16 \%$ gammaglobulin preparation intramuscularly (immunoglobulin anti-D SRK) within 48 hours of delivery, followed three days later by the rubella vaccine. Several patients had no alteration of rubella antibody titre three days after administration of this anti-D preparation. Three weeks and six weeks after the rubella vaccination, rubella HI-titres were found in both groups (see table). The conversion rate in both (admittedly small) groups was $100 \%$. Two patients responded poorly, one in group A with a titre of $1: 8$ six weeks after vaccination, another in group B with a titre of $1: 16$. The latter had received 3 units of blood at delivery.

\section{Results}

We conclude that the rubella antibodies administered with the anti-D immunoglobulin do not delay or prevent active immunity against the rubella virus when the vaccine is given at about the same time. Our 
Rubella Antibody Titres after Rubella Vaccination of Seronegative Patients

\begin{tabular}{|c|c|c|}
\hline & Group $A^{*}$ & Group B** \\
\hline Rubella HI-titre before vaccination in all patients & $<8$ & $<8$ \\
\hline $\begin{array}{l}\text { Rubella HI-titre three weeks after vaccination; } \\
\text { mean geometric titre } \pm 1 \text { S.D. }\end{array}$ & $\begin{array}{c}16 \cdot 9 \pm 9 \cdot 5 \\
(13)\end{array}$ & $\begin{array}{c}10 \cdot 4 \pm 6 \cdot 6 \\
(8)\end{array}$ \\
\hline $\begin{array}{l}\text { Rubella HI-titre six weeks after rubella } \\
\text { vaccination; mean geometric titre } \pm 1 \text { S.D. . }\end{array}$ & $\begin{array}{c}73 \cdot 5 \pm 2 \cdot 7 \\
(15)\end{array}$ & $\begin{array}{c}78 \cdot 8 \pm 2 \cdot 4 \\
(10)\end{array}$ \\
\hline P-value (six weeks) & & \\
\hline
\end{tabular}

*Patients received rubella vaccine on day 5 post partum

* Patients having had anti-D immunoglobulin within 48 hours of delivery followed three days later by the rubella vaccination.

results agree with those of others. ${ }^{2}{ }^{3}$ We do not hesitate, therefore, to inject anti-D when needed as well as the rubella vaccine post partum, but we also suggest postponing the rubella vaccination when a blood transfusion is given at delivery.

1 Alderman, B., and Charles, D. W., British Medical fournal, 1974, 2, 724.
2 Edgar, W. M., and Hambling, M. H., British Medical fournal, 1974, 3, 255. ${ }^{2}$ Edgar, W. M., and Hambling, M. H., British Medical fournal, 1974, 3,

University Department of Obstetrics and Gynaecology, 8006 Zürich, Switzerland

E. MARONI, M.D. Senior Lecturer

Institute of Medical Microbiology, Department of Virology, University of Zürich, 8006 Zürich, Switzerland

J. MUNZINGER, M.D. Senior Lecturer
Figures in parentheses indicate number of patients.

$\left({ }^{51} \mathrm{Cr}-\mathrm{EDT}\right.$ A space) at three, four, five, and six hours postinjection calculated from:

$$
(\text { Space })_{t}=\frac{\text { Activity injected }}{\text { Plasma concentration at time } t}
$$

The three-hour ${ }^{51} \mathrm{Cr}$-EDTA space is shown plotted against G.F.R. in the figure. From this the G.F.R. can be predicted from the space with a standard deviation of $8 \mathrm{ml} / \mathrm{min}$. Similar regression lines can be obtained for other periods. The best fit is obtained at four to five hours after injection; at six hours the error increases.

\section{Discussion}

The sample may be taken at any time during the three to five hour postinjection period, except when the G.F.R. is very low. A three-hour period fits conveniently into a single outpatient session, and additional later blood samples may be taken, if necessary, to confirm the initial estimate. If the regression line for four and five hours is plotted on the same chart, as shown dotted in the fig., the appropriate factor can be obtained by interpolation between the curves. In the absence of renal function, the volume of distribution of ${ }^{51} \mathrm{Cr}$-EDTA after the initial two to three hour period of equilibration corresponds approximately to the extracellular fluid volume (E.C.F.) ${ }^{3}$ and thereafter remains substantially constant. Provided the patient is not oedematous, the increasing excess ${ }^{51} \mathrm{Cr}$-EDTA space reflects the amount of tracer cleared by the kidneys and hence provides an index of the G.F.R.

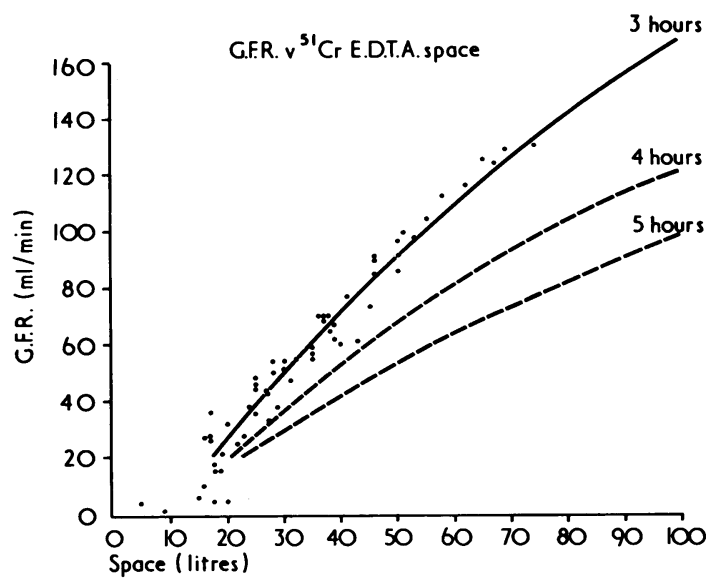

Experimental correlation between three hour ${ }^{51} \mathrm{Cr}$-EDTA space and GFR. The least squares fitted polynomial curves for four and five hours are also shown.

\section{Introduction}

Estimates of effective renal plasma flow (E.R.P.F.) and glomerular filtration rate (G.F.R.) are usually derived from analysis of the plasma disappearance curves of radionuclide labelled $o$-iodohippuric acid (Hippuran) and ${ }^{51} \mathrm{Cr}$-edetic acid ( ${ }^{51} \mathrm{Cr}$-EDTA), respectively, thus avoiding the necessity for urine collections. It is necessary to determine the entire concentration-time curve from the time of injection until the tracer is completely excreted, and the numerous published techniques represent different methods for reducing the number of blood samples required by introducing various approximations. For E.R.P.F. measurement Tauxe et al. ${ }^{12}$ extended this process to its logical limit when they showed that the apparent volume of distribution of radio-Hippuran derived from a single blood sample taken 44 minutes after injection ( 53 minutes in children) correlated very closely with the E.R.P.F. We have found that the same principle applies to the estimation of G.F.R.

\section{Methods and Results}

The technique based on the plasma clearance of ${ }^{51} \mathrm{Cr}$-EDTA described by Garnett et al., ${ }^{3}$ with the correction factors evaluated by Chantler $e t$ al. ${ }^{4}$ has Garnett $e t$ al., with the correction factors evaluated by Chantler et al., has
been in routine use for several years. The logarithmic decay constant of the been in routine use for several years. The logarithmic decay constant of the plasma activity curve is obtained using three blood samples taken over the period two to six hours after injection of the tracer, and multiplied by the
initial volume of distribution. The data from 73 consecutive routine G.F.R. initial volume of distribution. The data from 73 consecutive routine G.F.R.
measurements were examined and the apparent volume of distribution

At G.F.R. values below $30 \mathrm{ml} / \mathrm{min}$ the resulting absolute estimates are virtually useless because variations in E.C.F. between individuals (particularly our geriatric patients) contribute substantially to the scatter of the data. The use of the body surface area to make this factor normal may improve this and is being investigated; there is also some improvement if a five-hour sample can be obtained when the G.F.R. is feared to be low. At present the single sample technique appears to provide an estimate of the G.F.R. whose accuracy is comparable with that of the endogenous creatinine clearance but which is rapid and does not necessitate a 24-hour urine collection.

1 Tauxe, W. N., Maher, F. T., and Taylor, W. P., Mayo Clinic Proceedings, $1971,46,524$

2 Tauxe, W. N., Hagge, W., and Stickler, G. B., in Dynamic Studies with Radioisotopes in Clinical Medicine and Research, p. 265. Vienna, I.A.E.A., 1974.

3 Garnett, E. S., Parsons, V., and Veall, N., Lancet, 1967, 1, 818.

4 Chantler, C., Clinical Science, 1969, 37, 169.

Radioisotopes Division, Northwick Park Hospital and Clinical

Research Centre, Harrow, Middlesex, HA1 3UJ

M. FISHER, B.SC., Principal Physicist

N. VEALL, D.SC., F.INST.P., Head of Division 